Original article

\title{
Evaluation of antioxidant and DNA nicking potential along with HPTLC fingerprint analysis of different parts of Pterospermum acerifolium (L.) Willd
}

\author{
Rathinavelusamy Paramaguru ${ }^{a}$, Papiya Mitra Mazumder ${ }^{\mathrm{a}, *}$, Dinakar Sasmal ${ }^{\mathrm{a}}$, \\ Dhananjay Kumar ${ }^{\mathrm{b}}$, Kunal Mukhopadhyay ${ }^{\mathrm{b}}$ \\ ${ }^{a}$ Department of Pharmaceutical Sciences, Birla Institute of Technology, Ranchi 835215, Jharkhand, India \\ ${ }^{\mathrm{b}}$ Department of Biotechnology, Birla Institute of Technology, Ranchi 835215, Jharkhand, India
}

\section{A R T I C L E I N F O}

\section{Article history:}

Received 15 March 2013

Accepted 23 May 2013

Available online 22 August 2013

\section{Keywords:}

PT257R/T plasmid

LPO assay

$\mathrm{OH}$ radical scavenging activity

\begin{abstract}
A B S T R A C T
Objective: The present study was designed to evaluate the in vitro antioxidant and DNA nicking potential of various extracts and fractions of Pterospermum acerifolium (L.) Willd (Family: Stericuliaceae). Research design and methods: Antioxidant properties of the extracts and fractions was assayed by DPPH scavenging activity, non-site-specific and site-specific $\mathrm{OH}$ radical scavenging activity mediated 2-deoxyD-ribose degradation, total antioxidant activity and lipid peroxidation assay by using rat liver homogenate. DNA nicking assay was studied by PT257R/T plasmid. Estimation of total phenolic content and total flavonoid content was done. Further HPTLC fingerprint of active fractions was performed.

Results: Ethyl acetate fractions of leaves, flowers and bark exhibited potent antioxidant property and DNA protective effect compare to all the other extracts and fractions. Total phenolic and flavonoid content determination was also showed ethyl acetate fractions were rich in phenolic and flavonoid contents. HPTLC fingerprint revealed the total number of peaks present in the active ethyl acetate fractions of leaves, flowers and bark.

Conclusion: The present study indicated that, ethyl acetate fractions of leaves, flowers and bark showed effective antioxidant and DNA protection activity and it could be the initiation for various other pharmacological studies on those fractions.
\end{abstract}

Copyright $\odot$ 2013, SciBiolMed.Org and Phcog.Net, Published by Reed Elsevier India Pvt. Ltd. All rights reserved.

\section{Introduction}

Free radical is a chemical compound, which contains an unpaired electron spinning on the peripheral layer around the nucleus. The family of free radicals generated from the oxygen is called reactive oxygen species (ROS), which cause damage to other molecules by extracting electrons from them in order to attain stability. ${ }^{1}$ Due to over-production of reactive species, induced by exposure to external oxidants or a failure in the defense mechanisms, damage to cell structures, DNA, lipids and proteins occur which increases the risk of different diseases. ${ }^{2}$ Antioxidants thus play an important role to protect the human body against damage by reactive oxygen species. ${ }^{3}$ The body possesses antioxidant defense mechanisms such as enzymatic antioxidant systems (superoxide dismutase (SOD), glutathione peroxidase (GPx), catalase

\footnotetext{
* Corresponding author. Tel.: +91651 2275290.

E-mail address: pmitramazumder@bitmesra.ac.in (P.M. Mazumder).
}

(CAT) etc.) and non-enzymatic antioxidant systems (ascorbic acid (vitamin C), $\alpha$-tocopherol (vitamin E), glutathione (GSH), carotenoids, flavonoids, etc). Normal levels of antioxidant system in the body are not sufficient for the eradication of the free radical injury. ${ }^{4}$ Thus the need of the body for antioxidants from external sources becomes mandatory. Synthetic antioxidants like butylated hydroxytoluene (BHT) and butylated hydroxyanisole (BHA) commonly used have side effects and are also carcinogenic, ${ }^{2}$ thus there is a need for more effective, less toxic and cost effective antioxidants. Medicinal plants appear to have desired advantages and hence there occurs a growing interest in natural antioxidants from plant sources. ${ }^{1}$

Pterospermum acerifolium (L.) Willd (Family: Sterculiaceae) commonly known as kanakchampa, is an evergreen large tree up to $24 \mathrm{~m}$ in height and $2.5 \mathrm{~m}$ in girth with smooth bark, greyish brown in color. It is found in the sub-Himalayan tract and outer valleys from Yamuna eastwards to West Bengal, Assam and Manipur, up to an altitude of $1200 \mathrm{~m} .{ }^{5}$ It has been traditionally used for the treatment of blood troubles, inflammation, ulcer, tumors, leprosy, small pox 
eruptions, general tonic, diabetes, gastrointestinal disorder, bronchitis, cough, cephalic pain, migraine and antimicrobial agent. ${ }^{6,7}$ From leaves, kaempferol-3-0- $\beta$-D-galactoside $(0.3 \%)$ as the major flavonoid and luteolin, luteolin-7-0- $\beta$-D-glucoside, luteolin 7-0- $\beta$-D glucuronide were isolated. ${ }^{8}$ In flowers, $24 \beta$-ethylcholest-5-en-3beta- 0 -alpha-cellobiside, $\beta$-amyrin, $\beta$-sitosterol, $n$-triacontanol, $n$ hexacosane-1-26-diol dilignocerate and a mixture of acids and saturated hydrocarbon were isolated from the light petroleum ether extract of the dried flowers. ${ }^{9}$ In addition to that, $4^{\prime}$-(2-methoxy-4(1,2,3-trihydroxypropyl) phenoxy) luteolin, 5,7,3'-trihydroxy-6-O$\beta$-D-glucopyranosyl flavone, 3,5-dihydroxyfuran-2(5H)-one ${ }^{10}$ kaempferol and kaempferide-7-glucoside were isolated from the alcoholic extracts of the dried flowers. ${ }^{11}$ From barks, D-galacturonic acid, D-galactose and alpha-rhamnose in the molar ratio 5:3:3 were isolated. ${ }^{12}$ Pharmacological studies conducted in the plant are comparatively low. Hence this study is designed to evaluate the antioxidant and DNA nicking potential of the various extracts and fractions of leaves, flowers and bark of $P$. acerifolium along with their HPTLC fingerprint analysis of active fractions.

\section{Materials and methods}

\subsection{Plant materials}

Leaves, bark and flowers of $P$. acerifolium collected from the campus of BIT-Mesra, Ranchi in the month of August 2011. The plant material had been identified and authenticated from taxonomy department of National Botanical Research Institute (NBRI), Lucknow. The voucher specimens (NBRI/CIF/247/2011) were retained in the Department of Pharm. Sciences, BIT-Mesra, Ranchi for future reference.

\subsection{Extraction and fractionation}

Air dried coarsely powdered leaves $(1 \mathrm{~kg}$ ) was extracted with methanol for the period of $72 \mathrm{~h}$, filtered, concentrated on rotary evaporator (Buchi, US) to get $96.4 \mathrm{~g}$ of extract PALME. The obtained extract (25 g) was dissolved in distilled water and successive extraction with hexane (PALHF), ethyl acetate (PALEF) and the remaining residue as aqueous fraction (PALAF) and concentrated to dryness to obtained respective fractions.

Powdered flowers (1 kg) and bark (1 kg) was extracted separately with $50 \%$ ethanol for the period of $72 \mathrm{~h}$ and concentrated to get $61.32 \mathrm{~g}$ of $50 \%$ ethanol extract of flower PAFEE and $74.61 \mathrm{~g}$ of $50 \%$ ethanol extract of bark PABEE. Both the obtained extract ( $25 \mathrm{~g})$ was dissolved in distilled water and extracted successively with hexane (flower PAFHF and bark PABHF), chloroform (flower PAFCF and bark PABCF), ethyl acetate (flower PAFEF and bark PABEF) are concentrated to dryness to obtained respective fractions.

\subsection{Free radical scavenging activity using $D P P H$}

The ability of the samples to scavenge the free radicals was estimated by in vitro method using a stable nitrogen centered radical viz. DPPH. Scavenging of DPPH free radical determines the free radical scavenging capacity or antioxidant potential of the test sample, which shows its effectiveness, prevention, interception and repair mechanism against injury in a biological system. Extract $0.05 \mathrm{ml}$ dissolved in methanol was added to a methanolic solution of DPPH $(100 \mu \mathrm{M}, 2.95 \mathrm{ml})$ at different concentration $(200-1000 \mu \mathrm{g} / \mathrm{ml})$ and the absorbance was recorded at $517 \mathrm{~nm} .{ }^{13}$

$\mathrm{DPPH}$ scavenging activity $(\%)=[(\mathrm{AC}-\mathrm{AS}) / \mathrm{AC}] \times 100$ where AC is the absorbance value of the control and AS is the absorbance value of the added test samples solution.

\subsection{Hydroxyl radical scavenging activity}

\subsubsection{Non-site-specific $\mathrm{OH}$ radical scavenging activity mediated 2-deoxy-D-ribose degradation}

The deoxyribose method was used for determining the scavenging effect on $\mathrm{OH}$ as describe by Halliwell. ${ }^{14,15}$ The reaction mixture contained ascorbic acid $(50 \mu \mathrm{M}), \mathrm{FeCl}_{3}(20 \mu \mathrm{M})$, EDTA $(2 \mu \mathrm{M}), \mathrm{H}_{2} \mathrm{O}_{2}(1.42 \mathrm{mM})$, deoxyribose $(2.8 \mathrm{mM})$, with different concentrations of samples in a final volume of $1 \mathrm{ml}$ in potassium phosphate buffer ( $10 \mathrm{mM}, \mathrm{pH} 7.4)$. It was incubated at $37^{\circ} \mathrm{C}$ for $1 \mathrm{~h}$ and then $1 \mathrm{ml}$ of $2.8 \%$ TCA and $1 \mathrm{ml}$ of $1 \%$ TBA were added. The mixture was heated in a boiling water bath for $15 \mathrm{~min}$. It was cooled and absorbance was measured at $532 \mathrm{~nm}$ with the spectrophotometer (Shimadzu UV 1700).

\subsubsection{Site-specific $\mathrm{OH}$ radical scavenging activity mediated 2-deoxy-D-ribose degradation}

The ability of the extract to inhibit site-specific $\mathrm{OH}$ mediated degradation was also carried out to understand its role as a metal chelator. The reaction mixture contained ascorbic acid $(50 \mu \mathrm{M})$, $\mathrm{FeCl}_{3}(20 \mu \mathrm{M})$, buffer $(2 \mu \mathrm{M}), \mathrm{H}_{2} \mathrm{O}_{2}(1.42 \mu \mathrm{mM})$, deoxyribose (2.8 mM), with different concentrations of samples in a final volume of $1 \mathrm{ml}$ in potassium phosphate buffer $(10 \mathrm{mM}, \mathrm{pH} 7.4)$. It was incubated at $37^{\circ} \mathrm{C}$ for $1 \mathrm{~h}$ and then $1 \mathrm{ml}$ of $2.8 \%$ TCA and $1 \mathrm{ml}$ of $1 \%$ TBA were added. The mixture was heated in a boiling water bath for $15 \mathrm{~min}$. It was cooled and absorbance was measured at $532 \mathrm{~nm}$ with the spectrophotometer (Shimadzu UV 1700).14,15

\subsection{Total antioxidant capacity}

Total antioxidant capacity was measured according to spectrophotometric method. $0.1 \mathrm{ml}$ of the extract $(1000 \mu \mathrm{g} / \mathrm{ml})$ dissolved in water was added to an Eppendorf tube and combined with $1 \mathrm{ml}$ of reagent solution ( $0.6 \mathrm{M}$ sulfuric acid, $28 \mathrm{mM}$ sodium phosphate and $4 \mathrm{mM}$ ammonium molybdate). The tubes were capped and incubated in a thermal block at $95^{\circ} \mathrm{C}$ for $90 \mathrm{~min}$. After cooling to room temperature, the absorbance of the aqueous solution of each was measured at $695 \mathrm{~nm}$ against a blank. Ascorbic acid was used as the standard. ${ }^{13}$

\subsection{Assay of lipid peroxidation}

Male Wistar rats (160-180 g) were procured from the animal house of BIT-Mesra, Ranchi, India. All animals were kept in polyacrylic cages and maintained under standard housing conditions (room temperature $24-27{ }^{\circ} \mathrm{C}$ and humidity $60-65 \%$ with $12: 12$ light:dark cycles). Food was provided in the form of dry pellets and water ad libitum. The animals were allowed to get acclimatized to the laboratory conditions for 7 days before the commencement of the experiment. All experiments involving animals complied with the ethical standards of animal handling and approved by Institutional Animal Ethics Committee (BIT/PH/IAEC/34/2011).

Randomly selected rats were fasted overnight and were sacrificed by cervical dislocation, dissected and abdominal cavity was perfused with $0.9 \% \mathrm{w} / \mathrm{v}$ saline. Whole liver was taken out and visible clots were removed and a weighed amount of liver was processed to get a clear homogenate in cold phosphate buffered saline, pH 7.4 using glass Teflon homogenizer and filtered to get a clear homogenate. The degree of lipid peroxidation was assayed by estimating the thiobarbituric acid reactive substances (TBARS) by using the standard method with minor modifications. ${ }^{16}$ Briefly, different concentrations of samples $(200-1000 \mu \mathrm{g} / \mathrm{ml})$ were added 
to the liver homogenate. Lipid peroxidation was initiated by adding $100 \mu \mathrm{l}$ of this reaction mixture was taken in a tube containing $1.5 \mathrm{ml}$ of $0.67 \%$ TBA in $50 \%$ acetic acid. The mixture was heated in a hot water bath at $85{ }^{\circ} \mathrm{C}$ for $30 \mathrm{~min}$ and in a boiling water bath to complete the reaction. The intensity of the pink colored complex formed was measured at $535 \mathrm{~nm}$ in a spectrophotometer (Shimadzu UV 1700). The percentage of inhibition of lipid peroxidation was calculated by comparing the results of test with those of controls not treated with the extracts.

\subsection{DNA nicking assay}

\subsubsection{Isolation of DNA}

Plasmid was isolated by alkaline lysis method ${ }^{17}$ from overnight grown culture contain PT257R/T plasmid. Super coiled plasmid was eluted from the gel following the instruction of silica bead DNA gel extraction kit (Fermantas).

\subsubsection{Nicking assay}

DNA damage protective activity of extract was performed using super coiled PT257R/T DNA. A mixture of $10 \mu \mathrm{l}$ of sample $(40 \mu \mathrm{g} / \mathrm{ml})$ and plasmid DNA $(0.5 \mu \mathrm{g})$ was incubated for $10 \mathrm{~min}$ at room temperature followed by addition of $10 \mu \mathrm{l}$ of Fenton's reagent $(30 \mathrm{mM}$ $\mathrm{H}_{2} \mathrm{O}_{2}, 50 \mu \mathrm{M}$ ascorbic acid and $80 \mu \mathrm{M}$ of $\mathrm{FeCl}_{3}$ ). The final volume of mixture was made up to $20 \mu \mathrm{l}$ and incubated for $30 \mathrm{~min}$ at $37^{\circ} \mathrm{C}$. The DNA was analyzed on $1 \%$ agarose gel using ethidium bromide staining and photographed in Gel Doc (Gel doc, Syngene). Quercetin $(50 \mu \mathrm{M})$ was used as positive control. ${ }^{15,18}$

\subsection{Estimation of total phenolic content}

About $0.1 \mathrm{ml}$ of the sample $(10 \mu \mathrm{g} / \mathrm{ml})$ was mixed with $0.5 \mathrm{ml}$ of folin-Ciocalteu reagent (diluted with 1:10 ratio with distilled water) and $1.5 \mathrm{ml}$ of sodium carbonate. The mixture was shaken thoroughly and made up to $10 \mathrm{ml}$ with distilled water. The mixture was allowed to stand for $2 \mathrm{~h}$. The absorbance was measured at $750 \mathrm{~nm}$ using spectrophotometer (Shimadzu UV 1700). Gallic acid was used as standard and results were expresses as $\mathrm{mg} / \mathrm{g}$ gallic acid equivalent. $^{19}$

\subsection{Estimation of total flavonoid content}

About $0.5 \mathrm{ml}$ of the sample $(100 \mu \mathrm{g} / \mathrm{ml})$ was mixed with $1.5 \mathrm{ml}$ of methanol $(75 \% \mathrm{v} / \mathrm{v}), 0.1 \mathrm{ml}$ of aluminum chloride $(10 \% \mathrm{w} / \mathrm{v}), 0.1 \mathrm{ml}$ of potassium acetate $(1 \mathrm{M})$ and $2.8 \mathrm{ml}$ of distilled water. The mixture was allowed to stand for $30 \mathrm{~min}$ in room temperature. The absorbance was measured at $435 \mathrm{~nm}$ using spectrophotometer (Shimadzu UV 1700). Quercetin was used as standard and results were expresses as $\mathrm{mg} / \mathrm{g}$ quercetin equivalent. ${ }^{19}$

\subsection{HPTLC analysis}

A number of solvent systems were tried, and the satisfactory resolution was obtained in solvent system, dichloromethanemethanol (9:1) for leaf ethyl acetate fraction PALEF, dichloromethane-methanol (9.5:0.5) for flower (PAFEF) and bark (PABEF) ethyl acetate fraction.

Chromatographic separation of PALEF, PAFEF and PABEF was performed on $5 \mathrm{~cm} \times 10 \mathrm{~cm}$ aluminum-backed HPTLC plates coated with $200 \mu \mathrm{M}$ layers of silica gel 60GF254 (Merck, Darmstadt, Germany). Before use, the plates were prewashed with methanol and activated at $110{ }^{\circ} \mathrm{C}$ for $5 \mathrm{~min}$. All the three samples ( $5 \mu \mathrm{L}$ each) were applied on to HPTLC plate $13 \mathrm{~mm}$ apart from middle of bands by spray-on technique along with nitrogen gas supply for simultaneous drying of bands, by means of Camag (Switzer-land)
Linomat V sample applicator fitted with a $100 \mu \mathrm{L}$ syringe (Hamilton, Bonaduz, Switzerland). A constant spot application rate of $0.15 \mu \mathrm{L} / \mathrm{s}$ was used. Plates were developed with appropriate solvent system. Before development the chamber was saturated with mobile phase for $20 \mathrm{~min}$ at room temperature $\left(32 \pm 2{ }^{\circ} \mathrm{C}\right)$. Chromatography was performed in Camag's twin-trough chamber. Wavelength for detection was evaluated from complete UV spectrum. Scanning was performed with a Camag TLC scanner 3 under control of Camag winCATS planar chromatography manager software (version 1.4.2). The slit dimensions were $6 \mathrm{~mm} \times 0.45 \mathrm{~mm}$ and the scanning speed was $20 \mathrm{~mm} / \mathrm{s}$.

\subsection{Statistical analysis}

All data on all antioxidant activity tests are the average of triplicate analysis. Linear regression analysis was used to calculate the $\mathrm{IC}_{50}$ values.

\section{Results}

The findings from the experimental work have been summarized under different subheadings.

\subsection{Free radical scavenging activity using $D P P H$}

The free radical scavenging activity of extracts was studied by its ability to reduce the DPPH. In leaves, the extract PALME scavenged the DPPH radical with $\mathrm{IC}_{50}$ value of $469.83 \mu \mathrm{g} / \mathrm{ml}$ (Table 1 ). Amongst the fractions, the ethyl acetate fraction PALEF showed higher activity with low $\mathrm{IC}_{50}$ value of $223.67 \mu \mathrm{g} / \mathrm{ml}$ (Table 1 ) followed by, PALAF showing scavenging activity with $\mathrm{IC}_{50}$ value of $431.78 \mu \mathrm{g} / \mathrm{ml}$ (Table 1). In flowers, the ethyl acetate fraction PAFEF showed highest DPPH radical scavenging activity with $\mathrm{IC}_{50}$ value of $569.50 \mu \mathrm{g} / \mathrm{ml}$ (Table 2) compared to other extracts and fractions. Subsequently, the extract PAFEE $(569.50 \mu \mathrm{g} / \mathrm{ml})$ and chloroform fraction PAFCF (619.02 $\mu \mathrm{g} / \mathrm{ml}$ ) showed significant activity (Table 2). In bark, the ethyl acetate fraction PABEF showed the highest scavenging activity with $\mathrm{IC}_{50}$ value of $450.4 \mu \mathrm{g} / \mathrm{ml}$ (Table 3 ).

\subsection{Hydroxyl radical scavenging activity}

As the hydroxyl radical scavenging activity has been carried out using site-specific and non-site-specific method. It has been found that, there has been a considerable difference in the scavenging activity between both the methods. In leaves, non-site-specific method - $\mathrm{IC}_{50}$ values of $\mathrm{OH}$ radical scavenging activity ranges from 322.08 (PALEF) to $>1000 \mu \mathrm{g} / \mathrm{ml}$ (PALHF), site-specific method 276.42 (PALEF) to $943.95 \mu \mathrm{g} / \mathrm{ml}$ (PALHF) (Table 1). In flowers, nonsite-specific method $-\mathrm{IC}_{50}$ values of $\mathrm{OH}$ radical scavenging activity ranges from 396.30 (PAFEF) to $>1000 \mu \mathrm{g} / \mathrm{ml}$ (PAFHF), site-specific

Table 1

Antioxidant activity of methanolic extract of Pterospermum acerifolium leaves and its various fractions.

\begin{tabular}{llllllll}
\hline \multirow{2}{*}{ Test } & \multicolumn{3}{l}{ IC 50 values $(\mu \mathrm{g} / \mathrm{ml})$} & & \multicolumn{2}{l}{ Inhibition \% } \\
\cline { 2 - 4 } & PALME & PALHF & PALAF & PALEF & & $\begin{array}{l}\text { Ascorbic } \\
\text { acid }\end{array}$ & Quercetin \\
\hline DPPH & 469.83 & $>1000$ & 431.78 & 223.67 & 92.13 & - \\
LPO & 431.82 & $>1000$ & 523.33 & 335.75 & - & 86.48 \\
NS-OH & 363.82 & $>1000$ & 644.69 & 322.08 & - & 83.71 \\
$\quad$ radical & & & & & & 88.64 \\
S-OH radical & 276.4 & 943.95 & 546.45 & 277.36 & - &
\end{tabular}

NS-OH radical - Non-site-specific OH radical scavenging activity; S-OH radical Site-specific $\mathrm{OH}$ radical scavenging activity. 
Table 2

Antioxidant activity of $50 \%$ ethanolic extract of Pterospermum acerifolium flowers and its various fractions.

\begin{tabular}{|c|c|c|c|c|c|c|}
\hline \multirow[t]{2}{*}{ Test } & \multicolumn{4}{|c|}{$\mathrm{IC}_{50}$ values $(\mu \mathrm{g} / \mathrm{ml})$} & \multicolumn{2}{|c|}{ Inhibition \% } \\
\hline & PAFEE & PAFHF & PAFCF & PAFEF & $\begin{array}{l}\text { Ascorbic } \\
\text { acid }\end{array}$ & Quercetin \\
\hline DPPH & 569.50 & $>1000$ & 619.02 & 330.61 & 92.13 & - \\
\hline LPO & 347.73 & $>1000$ & 768.4 & 241.25 & - & 86.48 \\
\hline $\begin{array}{l}\mathrm{NS}-\mathrm{OH} \\
\quad \text { radical }\end{array}$ & 543.61 & $>1000$ & 768.86 & 396.30 & - & 83.71 \\
\hline $\mathrm{S}-\mathrm{OH}$ radical & 455.41 & $>1000$ & 694.56 & 340 & - & 88.64 \\
\hline
\end{tabular}

NS-OH radical - Non-site-specific $\mathrm{OH}$ radical scavenging activity; S-OH radical Site-specific $\mathrm{OH}$ radical scavenging activity.

Table 3

Antioxidant activity of 50\% ethanolic extract of Pterospermum acerifolium bark and its various fractions.

\begin{tabular}{|c|c|c|c|c|c|c|}
\hline \multirow[t]{2}{*}{ Test } & \multicolumn{4}{|c|}{$\mathrm{IC}_{50}$ values $(\mu \mathrm{g} / \mathrm{ml})$} & \multicolumn{2}{|c|}{ Inhibition \% } \\
\hline & PABEE & PABHF & PABCF & PABEF & $\begin{array}{l}\text { Ascorbic } \\
\text { acid }\end{array}$ & Quercetin \\
\hline DPPH & 627.06 & $>1000$ & 717.78 & 450.4 & 92.13 & - \\
\hline LPO & 709.58 & $>1000$ & 927.08 & 533.78 & - & 86.48 \\
\hline $\begin{array}{l}\mathrm{NS}-\mathrm{OH} \\
\text { radical }\end{array}$ & 688.93 & $>1000$ & 854.05 & 548.43 & - & 83.71 \\
\hline $\mathrm{S}-\mathrm{OH}$ radical & 595.86 & $>1000$ & 773.95 & 452.04 & - & 88.64 \\
\hline
\end{tabular}

NS-OH radical - Non-site-specific OH radical scavenging activity; S-OH radical Site-specific $\mathrm{OH}$ radical scavenging activity.

method 340 (PAFEF) to $>1000 \mu \mathrm{g} / \mathrm{ml}$ (PAFHF) (Table 2). In bark, non-site-specific method $-\mathrm{IC}_{50}$ values of $\mathrm{OH}$ radical scavenging activity ranges from 548.43 (PABEF) to $>1000 \mu \mathrm{g} / \mathrm{ml}$ (PABHF), sitespecific method -452.04 (PABEF) to $>1000 \mu \mathrm{g} / \mathrm{ml}$ (PABHF) (Table 3).

\subsection{Total antioxidant capacity}

In leaves, the total antioxidant percentage is highest in ethyl acetate fraction (PALEF - 81.63\%) followed by PALME (72.61\%), PALAF (68.21\%) and PALHF (30.16\%) in decreasing order. In flowers, the ethyl acetate fraction (PAFEF) showed the highest antioxidant percentage value (77.32\%), which subsequently decreased in PAFEE (68.20\%), PAFCF (51.71\%) and PAFHF (35.33\%). Similar observations have been noticed in the bark extracts. The total antioxidant percentage ranges from highest of $73.2 \%$ for PABEF followed by $66.32 \%$ for PABEE, $46.81 \%$ for PABCF to a lowest of $32.14 \%$ for PABHF.

\subsection{Assay of lipid peroxidation}

In leaves, the extract PALME inhibits the LPO with $\mathrm{IC}_{50}$ value of $431.82 \mu \mathrm{g} / \mathrm{ml}$ (Table 1). The ethyl acetate fraction PALEF showed highest LPO inhibition potential with IC $_{50}$ value of $335.75 \mu \mathrm{g} / \mathrm{ml}$ (Table 1). In flowers also amongst the extract and fractions, the ethyl acetate fraction PAFEF showed highest LPO inhibition potential with $\mathrm{IC}_{50}$ value of $241.25 \mu \mathrm{g} / \mathrm{ml}$ (Table 2). In bark, the ethyl acetate fraction PABEF showed the highest activity with $\mathrm{IC}_{50}$ value of $533.78 \mu \mathrm{g} / \mathrm{ml}$ (Table 3).

\subsection{DNA nicking assay}

In DNA nicking assay, excluding n-hexane fraction of all the three parts of $P$. acerifolium offered protection against the damage of super coiled plasmid DNA induced by $\mathrm{OH}$ radical. The ethyl acetate fractions of leaf (PALEF) and flower (PAFEF) showed the most effective protection and the action was very close to that of quercetin $(50 \mu \mathrm{M})$ (Fig. 1$)$.

\subsection{Total phenolic content}

Total phenolic content (TPC) was estimated by using folinCiocalteu reagent and expressed as $\mathrm{mg} / \mathrm{g}$ gallic acid equivalent (GAE). In leaves, ethyl acetate fraction PALEF showed high significant value of TPC about $377.50 \mathrm{GAE}$, followed by, extract PALME (305.00 GAE) and PALAF (236.25 GAE) which also showed the highest values. In flowers and bark, ethyl acetate fraction PAFEF (321.25 GAE), PABEF (257.50 GAE) and extract PAFEE (287.50 GAE), PABEE (230 GAE) showed significant values.

\subsection{Total flavonoid content}

Total flavonoid content (TFC) was estimated and expressed as $\mathrm{mg} / \mathrm{g}$ quercetin equivalent. In leaves, ethyl acetate fraction PALEF showed the highest value of TFC ( $270 \mathrm{mg} / \mathrm{g}$ quercetin equivalent), followed by, extract PALME (208.3 $\mathrm{mg} / \mathrm{g}$ quercetin equivalent). In flowers and bark, ethyl acetate fraction PAFEF ( $315 \mathrm{mg} / \mathrm{g}$ quercetin equivalent), PABEF (210 mg/g quercetin equivalent) and extract PAFEE (216 mg/g quercetin equivalent), PABEE (142 mg/g quercetin equivalent) showed high values as compared to other fractions.

\subsection{HPTLC analysis}

Based on the above results, HPTLC fingerprinting of ethyl acetate fractions (PALEF, PAFEF, PABEF) was taken. In HPTLC fingerprint observations, ethyl acetate fraction of leaves (PALEF), flowers

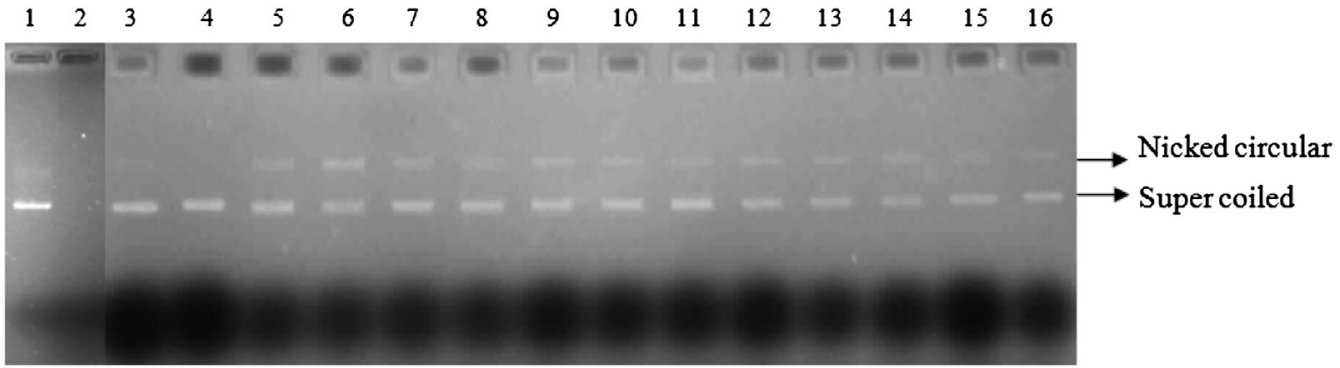

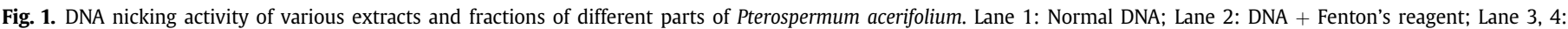

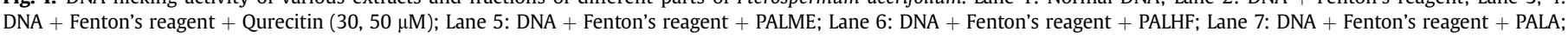

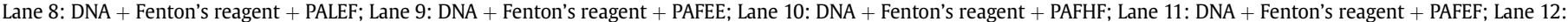

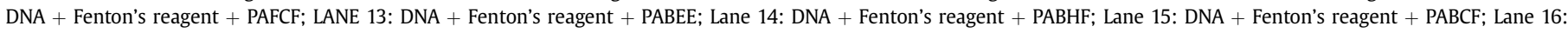
DNA + Fenton's reagent + PABEF. 
Table 4

HPTLC profile of PALEF, PAFEF and PABEF.

\begin{tabular}{llllrl}
\hline Fraction & Peak & $R_{\mathrm{f}}$ & Max. height & Area & Area \% \\
\hline PALEF & 1 & 0.64 & 142.9 & 7086.5 & 61.79 \\
& 2 & 0.85 & 120.9 & 4381.3 & 38.21 \\
& 3 & 0.77 & 100.5 & 3606.0 & 66.96 \\
& 4 & 0.59 & 82.1 & 1779.0 & 33.04 \\
& 5 & 0.87 & 52.0 & 940.4 & 39.69 \\
PAFEF & 6 & 0.65 & 18.1 & 385.1 & 18.35 \\
& 1 & 0.60 & 204.4 & 6902.0 & 58.42 \\
& 2 & 0.33 & 197.5 & 5546.8 & 43.85 \\
& 3 & 0.26 & 178.3 & 6653.4 & 36.35 \\
& 4 & 0.51 & 47.0 & 1086.4 & 8.59 \\
PABEF & 5 & 0.42 & 34.4 & 600.0 & 5.68 \\
& 1 & 0.39 & 27.2 & 636.5 & 25.78 \\
& 2 & 0.62 & 11.6 & 275.2 & 11.15 \\
& 3 & 0.26 & 186.1 & 8183.8 & 49.92 \\
& 4 & 0.53 & 126.5 & 8209.8 & 50.08 \\
\hline
\end{tabular}

(PAFEF) and bark (PABEF) exposed several peaks (Table 4). The resultant chromatograms are showed in Figs. 2 and 3. Ethyl acetate fraction of leaves PALEF showed six peaks with $R_{\mathrm{f}}$ values in the range of $0.59-0.87$ in the optimized solvent system of dichloromethane-methanol (9:1) (Table 4). The peak number 3 showed higher percentage of area of about $66.96 \%$ (Table 4 and Fig. 2). Ethyl acetate fraction of flowers PAFEF showed five peaks with $R_{\mathrm{f}}$ values in the range of $0.26-0.60$ in the optimized solvent system of dichloromethane-methanol (9.5:0.5) (Table 4). The peak number 1 showed higher percentage of area of about 58.42\% (Table 4 and Fig. 3a). Ethyl acetate fraction of bark PABEF showed four peaks with $R_{\mathrm{f}}$ values in the range of $0.26-0.62$ in the optimized solvent system of dichloromethane-methanol (9.5:0.5) (Table 4). The peak number 3 and 4 showed higher percentage of area of about 49.92 and $50.08 \%$ respectively (Table 4 and Fig. $3 b$ ).

\section{Discussion}

In a normal healthy person, the generation of pro-oxidants in the form of ROS and RNS are effectively kept in check by the various levels of antioxidant defense mechanisms. However, when it gets exposed to adverse physicochemical, environmental or pathological agents such as atmospheric pollutants, cigarette smoking, ultraviolet rays, radiation, toxic chemicals, over nutrition and advanced glycation end products (AGEs) in diabetes, this delicately maintained balance is shifted in favor of pro-oxidants resulting in 'oxidative stress'. ${ }^{20}$ Due to the increased carcinogenicity effects of synthetic antioxidants, interest has increased toward natural antioxidants as it is having fewer side effects.
The antioxidant activity of the extracts and fractions were analyzed by various in vitro antioxidant assay techniques. The free radical scavenging activity using DPPH is based up on the extract's ability to reduce the DPPH, a stable free radical. If a molecule that can donate an electron or hydrogen to DPPH, it can also react with it and thereby bleach the DPPH absorption. DPPH is a purple colour dye having absorption maxima of $517 \mathrm{~nm}$ and upon reaction with a hydrogen donor the purple colour fades or disappears due to conversion of it to 2,2-diphenyl-1-picryl hydrazine resulting in decrease in absorbance. ${ }^{4}$ In this study, ethyl acetate fractions of leaves (PALEF), flower (PAFEF) and bark (PABEF) showed the highest $\mathrm{DPPH}$ scavenging activity with low $\mathrm{IC}_{50}$ values. Hydroxyl radical scavenging activity can be done under two conditions to derive two separate inferences, role on hydroxyl trapping ('nonsite-specific assay', where EDTA is added) and role of metal chelation ('site-specific assay', where no EDTA is added). ${ }^{15}$ Reducing agents like ascorbic acid can produce $\mathrm{OH}$ radical by reducing $\mathrm{Fe}^{3+}$ to $\mathrm{Fe}^{2+}$ that degrade deoxyribose using $\mathrm{Fe}^{2+}$ salts as an important catalytic component and oxygen radicals may attack the sugar, which leads to sugar fragmentation. Addition of transition metal ions such as iron at low concentrations to deoxyribose causes degradation of the sugar into malondialdehyde and other related compounds which form a chromogen with thiobarbituric acid (TBA). ${ }^{21}$ Here the ethyl acetate fractions of all the three parts of P. acerifolium, PALEF, PAFEF and PABEF showed maximum inhibition in both non-site-specific and site-specific $\mathrm{OH}$ radical scavenging methods with minimum $\mathrm{IC}_{50}$ values. The total antioxidant activity (phosphomolybdenum method) is based on the reduction of Mo (VI) to Mo $(\mathrm{V})$ by the sample analyte and the subsequent formation of green phosphate Mo (V) complex with a maximum absorption at $695 \mathrm{~nm}^{22}$ The ethyl acetate fractions reduced molybdenum VI to a green colored phosphomolybdenum $\mathrm{V}$ complex significantly.

The inhibition of lipid peroxidation induced by ferrous sulfate in liver homogenate was assayed by measuring the amount of lipid peroxidation product malondialdehyde. Oxidative stress can lead to peroxidation of cellular lipids and can be measured by determining the levels of thiobarbituric acid reactive substances (TBARS). The ethyl acetate fractions of leaves, flowers and bark showed potent lipid peroxidation inhibition by reducing the formation of lipid peroxidation end product malondialdehyde. Hydroxyl radical generated by the Fenton's reaction is also known to cause oxidative induced breaking of DNA strands to yield the open circular or relaxed forms. ${ }^{15}$ PALEF and PAFEF showed effective reduction in the formation of nicked DNA and increased super coiled form of DNA. Ethyl acetate fractions of all the examined parts of the plant namely leaf, flower and bark (PALEF, PAFEF, PABEF) showed higher phenolic and flavonoid content as compared to their own fractions and justifies their well-built antioxidant activity. HPTLC is sensible
Track 2, ID: LEAVES 15MCG

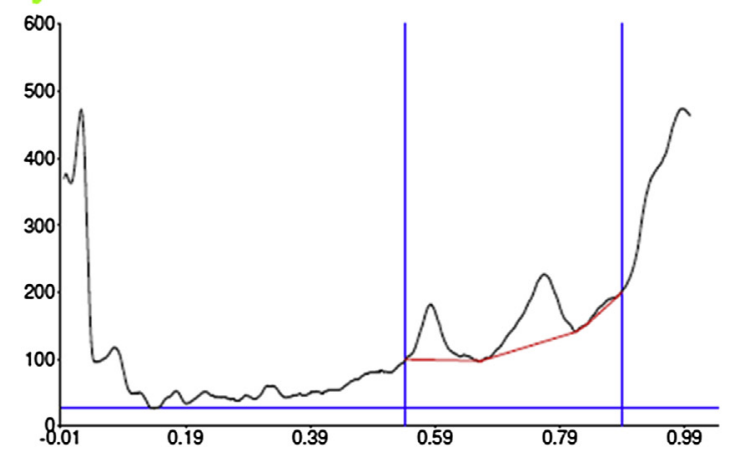

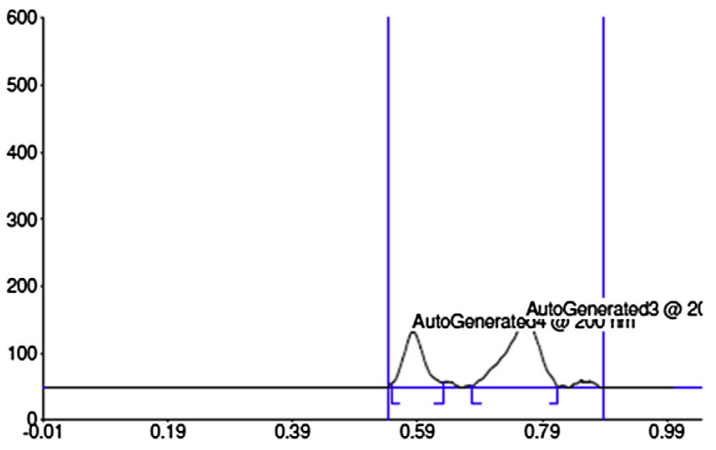

Fig. 2. HPTLC chromatogram of PALEF peak number 3 (AutoGenerated 3) scanned at $200 \mathrm{~nm}$. 
a

| Track 1, ID: FLOWER

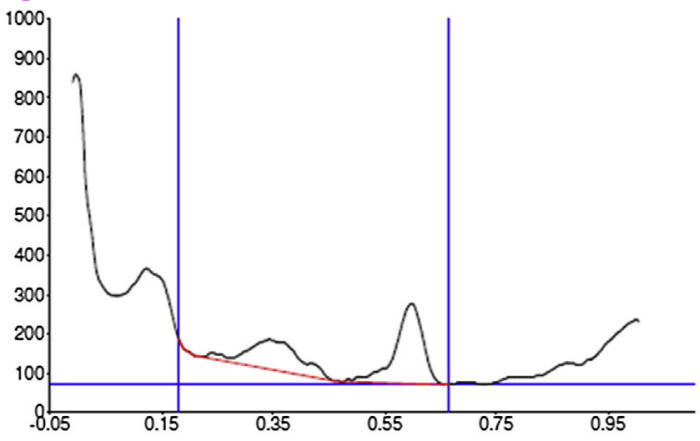

b

Track 2, ID: BARK

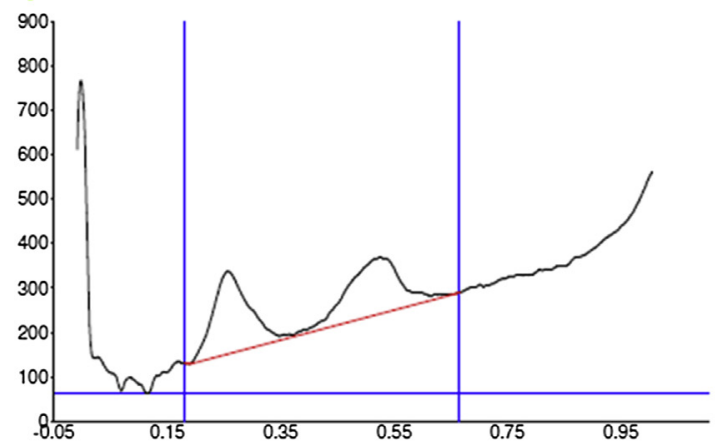

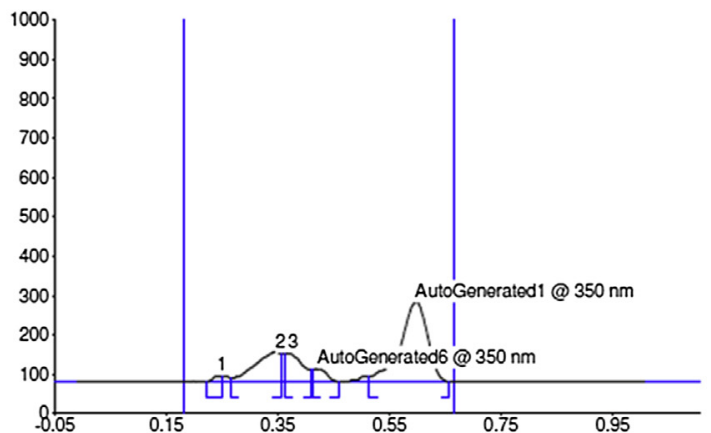

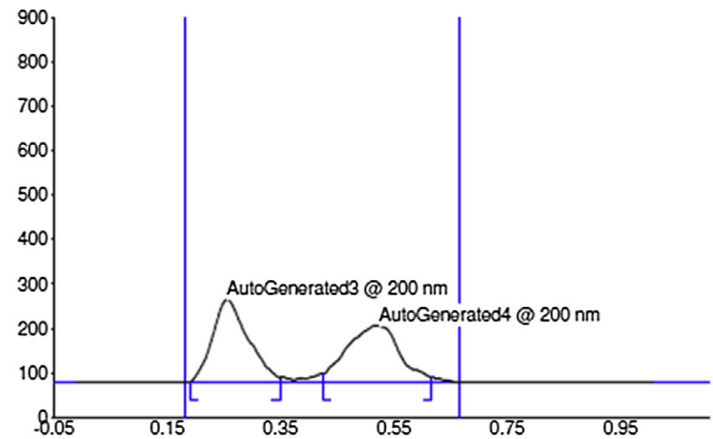

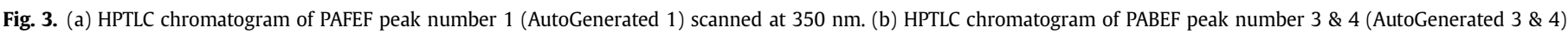
scanned at $200 \mathrm{~nm}$.

method for development of chromatographic fingerprints to determine major active constituents of medicinal plants. In the present study, the HPTLC chromatogram of active ethyl acetate fraction of leaves (PALEF), flowers (PAFEF) and bark (PABEF) of $P$. acerifolium was established. Further works to isolate, characterize and quantitatively estimate with the marker compound of active constituents are in progress.

\section{Conclusion}

The work demonstrated the in vitro antioxidant and DNA nicking potential of different extract and fractions obtained from various parts of $P$. acerifolium and it was found that the ethyl acetate fraction of leaf, bark and stem were the most active fractions. Further work with these active fractions to isolate the active constituents and pin point on its MOA as antidiabetic agent is in progress. This could form the basis for various other pharmacological studies in active fractions.

\section{Financial support}

This work was financially supported by University Grant Commission (UGC) under the scheme of Major research project, New Delhi, India (Grant No: F.39-157/2010 (SR)).

\section{Conflicts of interest}

All authors have none to declare.

\section{Acknowledgments}

The authors would like to acknowledge Department of Pharmaceutical Sciences and Biotechnology, Birla Institute of Technology, Mesra, Ranchi, India for providing the necessary facilities to carry out the study and University Grants Commission (UGC) for providing financial assistance.

\section{References}

1. Chanda S, Dave R. In vitro models for antioxidant activity evaluation and some medicinal plants possessing antioxidant properties: an overview. Afr J Microbiol Res. 2009;3:981-996.

2. Ali SS, Naresh $\mathrm{K}$, Abhinav L, et al. Indian medicinal herbs as sources of antioxidants. Food Res Int. 2008;41:1-15.

3. Lollinger J. Free Radicals and Food Additives. London: Taylor and Francis; 1981: 121.

4. Paramaguru R, Silambujanaki P, Bavanieswaran M, Rao ChV, Rawat AKS, Vijayakumar M. Free radical scavenging and lipid peroxidation inhibition potential of various fractions of Murraya panniculata. Pharmacologia. 2012;3:138-143.

5. Mazumder PM, Sasmal D, Ghosh AR, Paramaguru R. Evaluation of antihyperlipidemic and antioxidant activity of Pterospermum acerifolium (L.) Willd. Pharmacol Online. 2011;3:128-146.

6. Kirtikar KR, Basu B. Indian Medicinal Plants. Dehradun: Bishen Singh and Mahendra Pal Singh Publishers; 1998:373-376.

7. Chatterjee A, Pakrashi SC. The Treaties on Indian Medicinal Plants. vol. 3. New Delhi: National Institute of Science Communication (CSIR); 1997:16.

8. Gunasegaren R, Subramaniam SS. Ind J Pharm Sci; 1979:72-76.

9. Rizvi S, Sultana T. Phytochemical studies of the flowers of Pterospermum acerifolium. Phytochem. 1972;2:856-858.

10. Dixit P, Khan MP, Swarnkar G, Chattopadhyay N, Maurya R. Osteogenic constituents from Pterospermum acerifolium Willd. flowers. Bioorg Med Chem Lett. 2011;21:4617-4621.

11. Varshney SC, Rizvi SAJ, Gupta PC. Chemical examination of flowers of P. acerifolium. Planta Med. 1972;4:358-363. 
12. Bisnoi P, Gupta PC. Structure of a new acid -polysaccharide from the bark of Pterospermum acerifolium. J Chem Soc. 1979;1:1680-1683.

13. Shen Q, Zhang B, Xu R, Wang Y, Ding X, Li P. Antioxidant activity in vitro of the selenium-contained protein from the Se-enriched Bifidobacterium animalis. Anaerobe. 2010;16:380-386.

14. Halliwell B, Gutteridge JMC. Free Radicals, Aging and Diseases, in Free Radicals Biology and Medicine. Oxford: Oxford University Press; 1989:419-422.

15. Verma AR, Vijayakumar M, Rao ChV, Mathela CS. In vitro and in vivo antioxidant properties and DNA damage protective activity of green fruit of Ficus glomerata. Food Chem Toxicol. 2010;48:704-709.

16. Govindarajan R, Vijayakumar M, Rao ChV, et al. Antioxidant potential of Anogeissus latifolia. Biol Pharm Bull. 2003;27:1266-1269.

17. Sambrook J, Russell WD. In: Molecular Cloning a Laboratory Manual. 3rd ed. Newyork: Clod Spring Harbor Laboratory Press; 2001.
18. Lee JC, Kim HR, Kim J, Jang YSJ. Antioxidant property of an ethanol extract of the stem of Opuntia ficus-indica Var. Saboten. J Agri Food Chem. 2002;50:6490-6496.

19. Senthil Kumar R, Rajkapoor P, Perumal P. Antioxidant activities of Indigofera cassioides Rottl. Ex. DC. Using various in vitro assay models. Asian Pac J Trop Biomed; 2012:256-261.

20. Devasagayam TPA, Tilak JC, Boloor KK, Ketaki SS, Saroj SG, Lele RD. Free radicals and antioxidants in human health: current status and future prospects. J Assoc Physicians India. 2004;52:794-804.

21. Kumar Rajesh, Hemalatha S. In-vitro antioxidant activity of alcoholic leaf extract and subfractions of Alangium lamarckii Thwaites. J Chem Pharm Res. 2011;3:259-267.

22. Subhashini N, Thangathirupathi A, Lavanya N. Antioxidant activity of Trigonella foenum graecum using various in vitro and ex vivo models. Int J Pharm Pharm Sci. 2011;3:96-102. 